\title{
清酒醉造 と有機酸
}

\author{
本稿は長年清酒と有機酸の関係を研究されてきた筆者に, 原料から \\ 清酒に至るまで，各工程別に主要な有機酸の消長を概説していただい \\ たものである。香味之密接な関係を持つ清酒中の有機酸の起因を推定 \\ し，製造管理の要点を理解していただけることと思う。 \\ (編集部)
}

\section{上田 隆 蔵/大阪大学工学部}

\section{1. まえがき}

清酒醇造と有機酸の関係については, 酸度が酛, 醪の 発酵管理に使用されており，また清酒中の有機酸が香味 と密接な関係があることから，多数の研究者により検討 されてきた。これらの研究は最近䓹沼氏によって明解に 紹介されている。重復をさけるため, ここでは著者らの 研究を中心にして筆を進めることにする。

著者らの研究を紹介する前に, 生物と有機酸の関係に ついて概説することにする。リンゴにリンゴ酸, ミカン にクエン酸が多量含まれ，黒徽によってクエン酸，酵母 によってコハク酸，乳酸菌によって乳酸が主に生成され， 動物の筋肉飞乳酸が蓄積されることは上く知られてい る。このよ5に，生物はそれぞれ特有の有機酸代謝を行 ならが, 一般的な傾向として, 植物, 徽および酵母では 主としてリンゴ酸, クェン酸, コハク酸などの TCA サイクルに属する有機酸を蓄積し, 一方, 動物, 細菌は 乳酸，酶酸，酪酸などの TCA サイクルに属さない有機 酸を蓄積し，TCA サイクルの有機酸をむしろ資化する 傾向が認められる。ブドウ酒製造に执いて, 乳酸菌によ ってリンゴ酸より乳酸が生成される反応をマロラクチッ ク発酵と呼ばれているが，この発酵と同じ反応が清酒醸 造の生配系酒母, 製䊝工程, 清酒の腐造の場合にも行な われていると考兄られる。また, 同一菌株, 同一品種で あっても培盖（栽培）条件または製造型式により,さら には培養のフェース（熟成度）などにより有機酸代謝あ るいは蓄積の程度は異なってくる。たとえば橎菌の液体 培養, 米䴯の場合にはクエン酸が最も多量に生成される
が，しょう油麴の場合には原料中に含まれるクエン酸が 著しく減少する。いま 1 つの特徵は有機酸の変化が他の 成分にくらべて非常に大きいことである。したがって, 有機酸の変化を詳細にしらべることによって, 実際にど のような微生物がぞの程度活動したかをある程度知るこ とができる。酛, 醪の発酵管理に酸度が用いられている が，これが適切であることは上述のことより特わかり戴 けると思う。しかしながら, 酸度の測定では細菌污染め るいは野性酵母の污染を完全に予知することは不可能と 考觉られ，新しい管理方式の開拓が必要である。

それ故, ここでは原料より清酒までの酲造工程におけ る有機酸の消長の概略と, これらの研究によって酸度な どによって予知し兄ない腐造预よび家つき酵母あるい 野生酵母などの污染に対して有機酸, とくに酶酸の測定 が有効であることについて述べることにする。

\section{2. 原 料 米}

現在，好適米，一般米郝よび外米が用いられているが， この 3 者の間に成分的な相違があるかどらかは非常に重 要な問題である。有機酸よりみた場合, 好適米, 一般米 の間には注とんど差は認められない。しかしながら，内 地米と外米を比較した場合, 酢酸, フマル酸が外米の方 に多い傾向がある。これが，米自体によるか，または輸 送あるいは睁蔵中に生成したものであるかについては明 らかでないが，後者の影響も無視できないようである。 いま 1 つ興味あることはビルマ米, 蓬萊米のリンゴ酸含 量が他にくらべて非常に高い値を示したことである。

つぎに, 精米工程と有機酸の関係であるが, 米の部位 
の5ちで総有機酸量を最も多く含んでいるのは肧芽であ り, ついで精米 5 分後に得られた棣で, ともにクェン酸 が圧倒的に高い值を示している。玄米の総有機酸量が, 0.035 0.076\%であるのに対し, 胚芽では $0.455 \%$ であ る。約 $80 \%$ の精米率までは, 精米が進むにつれて各有 機酸とも急激に減少するが，それ以後 $60 \%$ までは増加， 減少をくり返しながら全体としては減少の傾向を示す。 そして，60\% の精米と玄米をくらべた場合，ほとんど の有機酸は玄米の方が高い值を示すが，リンゴ酸は $60 \%$ 精米の方が高い值を示した。米崎らがデンプン細胞層の 構造と一般成分との関係などを詳細倹討しているが, 有機酸もデンプン細胞層の構造と密接な関係があるよう である。

内地産玄米に打いて, 総有機酸量, クエン酸抢よびフ マル酸と脂肪との間に負の相関関保があり，一方に括い て脂肪の多い肧芽, 糠層にクエン酸含量が多く, 脂肪と クエン酸の間には密接な関係があるようである。クエン 酸, リンゴ酸の蓄積の機構は明らかでないが, 米粒の構 造, 各成分のバランスに対し重要な役割を演じているよ ろである。

\section{3. 製}

楼

製枆工程に抢いて, 枆菌以外に酵母, 細菌などの微生 物が多数存在することはよく知られている。また, 最近 では麴菌と酵母の関係も明らかにされている。著者らが， 米剓，しょら油棅について種々の角度より検討した結果 を概説する。

一般に, 有機酸の变化は盛込夕以前と盛込又以後の 2 つに大別される。盛込及以前の变化はそれ以後にくらべ て比較的少ないが，21時間後に乳酸, 酢酸のピークが喼 められる。しょう油麴に拉いても同じ傾向が認められる が，米棅にくらべてはるが大き。この乳酸，眽酸の 生成は乳酸菌あるいは Micrococcusなぞの細菌によるも のであろう。この乳酸の生成量は種䅗拉よび䴯室の微生 物の分布, 温度, 湿度, 㮃の水分含量, 種樉の使用量, 酸素供給条件などによって異なる。細菌数の少ない種

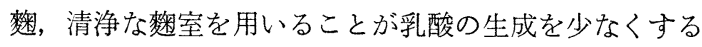
有力な手段ではないかと思われる。数の細菌污染度に対 して細菌酸度が用いられているが，20〜25 hr 後の乳酸 量を測定するのも 1 つの方法ではないかと思われる。

盛込久以後, 総有機酸量は急激汇增加するが, これは 主に TCA サイクルに属する有機酸の増加によるもので 出る。とくに, クエン酸の増加が著しく, 仲仕事以後常 汇総有機酸量の $60 \%$ を占めた。これらの有機酸の変化 は麳菌によってもたらされたものであり, 初期活躍し た細菌の作用はあまり認められない。
以上のことより，仕込当初楿菌よりも增殖速度の大き い細菌，酵母などが增殖代謝を行ならが，20〜25 hr 頃 より猌菌の增殖とともにその作用は漸次抑制され，30hr 以後麳菌の作用が主体となる。したがって, 出麴の有機 酸組成は㮃菌の代謝生産物であるクエン酸, リンゴ酸, コハク酸などが主体を占め, 乳酸量牥試料によって著し く異なる。

\section{4. 酛}

A 各種酛の比較 現在, 酒母としては生酛, 山廃酛, 速醸配, 高温桾化酛が用いられている。この 4 つの配で は製造方法, 微生物の動態が異なるから, 当然有機酸の 変化あるいは枯らし酛の有機酸含量が異なってもよい性 ずである。

生酛系酒母（枯らし時）の滴定酸度が速醸系酒母（枯 らし時）よりも高いことは衆知の事実であるが，これは 生酛系酒母の方が後者にくらべて乳酸，酢酸が高いから である。逆に、 コハク酸は速醸系の方が高い值を示して いる。山廃酛と生䤀との相違を成分的に見出すことはな かなかむずかしいが，酢酸に拈いて生酛の方が高い值 を示した。

このような相違が酛経過のどの時期に执いてもたらさ れたかといらことは酸度增加との関連に扔いて重要なこ とである。まず，生酛系酒母では䁔気入れ前の有機酸の 変化は比較的少なく，暖気入れより涌付きまでの間では 乳酸, 酢酸の増加と蒸米, 冞より由来するリンゴ酸, ク エン酸の減少が認められる。涌付き以後では乳酢, 酢酸 およびTCA サイクルに属する有機酸がいずれも增加す る。上述のよ5に，有機酸の変化は 3 つ分けられる が，これが現在まで明らかにされている微生物の動態と 極めてよく一致している。一方, 速醉系酒母で湧付き までに生酛系酒母に見られたような乳酸の顕著な增加は 認められない。湧付き以後の TCA サイクルに属する有 機酸の増加は速醸系の方が大きい。

ここで注目すべきことは酢酸，乳酸の変化である。酥 酸は全期間を通じて増加の傾向にあるが, 高温糖化配で はふくれまで注とんど増加せず，また山廃酛のように 12 日目から涌付きまでの期間注とんど増加しない場合 もあった。すなわち, 涌付きまでの酢酸の変化および涌 付き時の量は酛の型式および各酒造場の製造条件によっ て相当異なる。䣷酸はホモ型乳酸菌によってごく少量圱 成され，それ以外の細菌によっても生成されが，配の涌

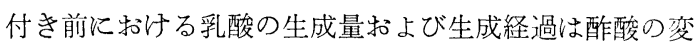
化扝よび量と相関性はないので, 酶酸の生成は乳酸菌以 外の細菌の作用を示していると解釈するのが妥当であろ う。涌付き以後の増加は醅母によるものであり，一般に 
酛 $100 \mathrm{~g}$ 当り約 $30 \mathrm{mg}$ 増加するのが普通であるが, 醅 母の種類によっては相当高い值を示す場合もある。

涌付き前の乳酸の生成は乳酸菌によるものであるが, 涌付き以後においても山廃酛で約 $200 \mathrm{mg}$, 高温糖化酛 では $100 \mathrm{mg}$ の増加が垫められる。この生成が酵母によ るか, 乳酸菌によるかという点について検討したところ， 山廃配に打いて $100 \mathrm{mg}$ 程度は明らかに乳酸菌によって 生成されているようである。しかしながら，乳酸菌の関 与が非常汇少ないと考兄られる高温糖化配においても前 述の上5に增加が認められることより, 相当量の乳酸が 酵母によって生成されている可能性も充分考光られる。 通常, 酵母によるアルコール発酵では乳酸は汪とんど生 成されないので, 涌付き以後の乳酸の増加は今後に残さ れた興味ある問題である。

な招，速䁔系酒母添加する飲料用乳酸はモノマーで ある $\mathrm{CH}_{3} \mathrm{CHOHCOOH}$ のほか, 乳酸が 2 分子あるいは 3 分子縮合した形の化合物が含まれている。すなわち，モ ノマー 57〜 62\%, ダイマー 20〜23\%, トリマー4 7.5 $\%$, テトラマー痕跡〜 $7 \%$ よりなっている。飲料用乳酸 が配に添加された場合, これらの重合物は加水分解して モノマーとなるが, 仮に全部加水分解された場合滴定酸 度は $20 \%$ 弱增加する。したがって, 配経過の酸度增加 のうちには乳酸重合物の分解によって生成されたものも 含まれていることを知って扣く必要があろう。

B 酛の発酵管理酛に拈ける細菌污染は乳酸菌によ るものであるが，著者らが遭遇した污染の場合の有機酸 組成を健全山廃配と比較すると次の上らである。

不良山廃酛の総有機酸量拉上び乳酸量は健全配の平均 值よりも高い值を示しているが, 最高値よりは低く、 コ ハク酸量も健全酛の平均値に注等しい值を示した。こ のことは酸度, ボーメ,アルコールなどの一般分析結果 あるいは状貌によって健全酛と不良酛の判定を行ならこ とが困難であることを示唆している。不良酛のピルビン 酸、リンゴ酸技よびクエン酸含量は少なく, 涌付き以後 に打いて恐らく酵母によって生成されたこれら有機酸が 乳酸菌によって資化されたものと推察される。最も明瞭 な相違は酷酸であり，不良酛は健全酛にくらべて明らか に高い值を示し，酶酸が酛の良否の判定に利用しらるこ とを認めた。

酢酸を発醅管理に利用するためには，同一酒造場また は同一型式の酛に执いて酢酸量がどの程度のバラッキに あるかを知っておく必要がある。著者らが同一蔵に招い て製造した枯らし 4 日後の山廃酛 9 種類について検討し た結果では, 総有機酸量および乳酸のバラッキは相当大 きかったが，酢酸およびュハク酸のバラッキは非常に少 なかった。このことは酶酸の測定が䤀の良否の判定に対
して極めて有利であることを示している。以上のことよ り, 酶酸量が異常に高い值を示す場合には, 乳酸菌劣よ び野生醭母の污染めるはは正常な微生物の動態でないと 判断して適当な処置をすべきであり,さらに枯らし時と 同時に涌付き時の酢酸量を測定すれば一層正確に管理し らるであろら。

\section{5. 醪}

A 醪工程における有機酸の消長 醪経過中の有機酸 の変化を山廃酛, 生配掞よび速醉配の 3 種類の酒母を用 いて検討してみた。山廃酛と速醸配を用いた醪はT酒造 場，生酛使用醪は $\mathrm{K}$ 酒造場のものである。

いずれの醪に扔いても有機酸の変化は大別して 4 つの フェースすなわち仕込みより留添完まで, 留添より5 日 まで 5 日より 10〜12 日頃えまで，およびそれ以後の期 間に分けられる。まず, 留添えまでの変化では物量の変 化により総有機酸量は顕著に減少し, 留添え時では全期 間を通じ最低值を示す。酢酸, 乳酸の減少の程度は比較 的大きく, TCA サイクルに属する有機酸の減少は比較 的少ない。これは蒸米, 窲中には TCA サイクルの有機 酸が多量含まれることより容易に推察しうることである。 ここで注目すべきことは生酛使用醪では初添えより踊り までの期間に括いて酢酸, 乳酸が減少しているのに対し， 山廃酛, 速醸配使用醪では若干増加していることであ る。この両酸の増加は細菌の作用によると考学るのが妥 当のようであり, 少なくとも一般分析結果から考兄て生 酛使用醪にくらべて酵母の増殖が遅れていることは明ら かである。

つぎに, 留添えより 5 日後までの間では, ほとんどの 有機酸が, やや増加するかまたは汪とんど変化しないか のいずれかであるが, 酰酸のみ顕著に減少した。5日後 より 10〜12 日頃まで変化は最も著しく，コハク酸，ビ ルビン酸, リンゴ酸および酢酸の増加が著しい。乳酸は， 全体として增加の傾向にあるが, 定常性ある変化を示さ なかった。10〜12 日以後の後発酵に打いては酸度，総、 有機酸量は汪とんど変化しないが，個々の有機酸はそれ， ぞれ特徵ある変化を示し, 量的変化も比較的大きい。酢 酸は上述の 3 つのフェースと最もよく一致した。

次に醪の有機酸の変化と微生物の動態との相関性を $\mathrm{H}$ 酒造場の山廃配使用醪について検討した。剓より由来し たと考兄られる好気性細菌 (Micrococcus が主体と考兄 られる）は急激に減少し，乳酸菌は極めてわずか存在す るが，漸減の傾向を示している。これら細菌の動態と有 機酸の消長との関連はほとんぞ認められなかった。一方, 酵母では, 明瞭に認められ, 酵母数の増加が認められる とき有機酸の増加はあまりなく, 酶酸は減少し,アルゴ 
一ルの增加が認められるときには有機酸は增加した。興 味あることは酵母の增殖が留後と $8 \sim 9$ 日後の 2 回認め られたことであり，8 日以後酵母の世代交替が行なわれ て二次的な発酔が行なわれたことを示している。

使用酛の影響は酛に括ける有機酸の差汪ど明瞭には認 められなかった。同一酒造場において製造された山廃酛 および速醸酛使用醪は酒造場の異なる生酛, 山廃配使用 醪に比べて比較的近似した変化を示し, 酛の種類よりも 各酒造場に抢ける大きな意味での醸造型式による影響の 方が大きいようである。

醪に括いて，コハク酸が最も多く生成され，ついでリ ンゴ酸の生成が多い。乳酸は得られた清酒中の 3 分の 2

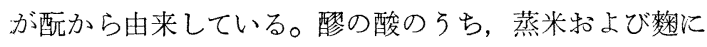
由来するものは約 $9.5 \%$, 酛に由来するものは $17 \%$ 強 であり，73\% 強が醪中で生成される。

B 醪の発酵管理 現在, 醪の微生物污染としては細

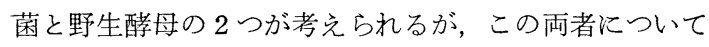
の実際例を示すと次のようである。

まず細菌污染の場合であるが，不良醪（速醸配使用） は留より 4 日後までの一般分析結果より判断して湧き遅 れの傾向があるが，その場合の有機酸の変化は健全醪と 比較して非常に異なっている。すなわち, 健全醪ではコ ハク酸, リンゴ酸が漸増して微弱ではあるがアリコール 発酵が行なわれていることを示唆している。一方不良醪 では両酸は注とんど変化せず，また乳酸の増加は前者よ りも後者の方が相当大きい。最も䫓著な相違は酶酸であ り上述のよ5に健全醪では顕著に減少するが，不良醪で は逆に增加している。不良醪は酢酸, 乳酸の増加より酵 母以外の微生物叔そらく乳酸菌の作用が考兄られる。こ の原因は酛の枯らし期間が長すぎたためと考觉られ，速 醸配では長期間の枯らしは危険であると思われる。

次に，野性酵母の污染の場合であるが，酵母の TTC 染色率 $80 \%$ pink を示酛を使用した醪に扣ける微生 物の動態と有機酸の消長との関係を追求した。仕込経過 の進行とともに酵母数は增加したが, その TTC 染色率 は活とんど変化しなかった。コハク酸, 乳酸, リンゴ酸, ピルビン酸の変化は上述の健全醪の場合々ほぼ同じパタ ーンを示したが，眽酸のみそのパターンが異なった。す なわち, 留後より 4 日ごろまでの酢酸の減少の程度が非 常に少なかった。

以上のように, 留後より数日間（最高ボーメ）の酢酸 の増減の程度を測定することにより, 細菌および野生酵 母の雨污染を察知しらることを認めた。一般に，健全な 場合の酢酸の最低值は留時の約 $20 \%$ であるが，現在ま でに, 10 例のうち8例がこのパターンを示すことを確 認している。

\section{6. 清}

\section{酒}

以上のことより, 清酒中の有機酸組成は種々の要因沉 より支配されているが，現在の清酒がどのよ5な有機酸 組成を示しているか，他の成分と比較した場合有機酸の もつ特徴は何か，製造方法によってどのよう潩なるか などは当然知って打く必要のあることである。著者らが 全国各地より集めた清酒 45 点（普通酒 35, 吟醉酒 5 , 山廃酛使用 6 , 速醸酛使用 28 , 混合酛使用 6 ）より兄ら れた結果を紹介するとつぎのようである。

滴定酸度および総有機酸量のバラッキは他の一般成分 にくらべて最も低く，成分的な面よりみて清酒醸造にお いて最も安定した成分といえよう。しかしながら，個々 の有機酸のバラッキはいずれも総有機酸量よりもはるか に高い值を示している。すなわち，滴定酸度は同じであ ってもその組成は非常に異なっていることを示してい る。そこで, 各有機酸相互の関係を検討してみると, 眽 酸が多い場合にはリンゴ酸が少ないとい5負の相関関係 が認められた。他の有機酸ではこのような関倸は認めら れなかったけれぞも，それぞれの有機酸が互いに量的に 相殺しあっていることが原因であり，酵母の代謝調節作 用の複雑さを示している。

滴定酸度と総有機酸量の間には正の相関が認められ, 配, 醪に括ける酸度增加が主に有機酸であることを示し ている。しかしながら， pH と総有機酸量の間には相関 関係は認められず，他の要因が影響していることを示し ている。

製造型式と有機酸の関係であるが，まず山廃系酒母を 用いた清酒は速醸系酒母を用いたものよりも乳酸含量が 高い。吟醸酒の総有機酸量は普通酒よりも低いが, 組成 的には顕著な相違は認められない。合成酒の総有機酸量 は清酒とほぼ同じ值であるが，合成酒のコハク酸量が極 端に高く, 乳酸, リンゴ酸酢, 酸などの有機酸はいずれ も相当低い值を示した。三增酒では普通酒よりもコハク 酸の含有比率が增加するが, 合成酒とは明確な相違が認 められる。カルロース米を用いた清酒の有機酸組成は内 地米を用いたものとほぼ同じ組成を示し，酢酸は外米臭 とは関係ないと思われる。腐造酒の総有機酸量は清酒と くらべて圧倒的に高いが, これは主として乳酸, 酶酸に よるものであり，コハク酸量は普通酒と差がなくアルコ 一ル発酵は充分行なわれたこと示している。昭和42酒 造年度に颃いて近畿地方では多酸酒が数多く見られたよ 5で离るが, 酸度 2.9 を示した清酒の総有機酸量は前述 の 45 点の清酒の総有機酸量の最高値よりも若干高く, 個々の有機酸について腐造酒と比較すると，その組成は 全く異なり，乳酸菌による醪の污染とは考えられない。 
普通酒と比較して，いずれの有機酸も高い値を示してい るのが特徴である。この原因汇ついては機会があれば検 討したいと思っている。

\section{7. おわりに}

著者らが過去 10 年間研究してきた清酒醇造と有機酸 の関係について概説したが, 本研究によって清酒醸造過 程に蛙ける有機酸の消長の大要は充分把握できたと考兄 ている。しかしながら，その生成機構については未解決 の点が多い。一方に抒いて，近年醸造過程の合理化，機 械化によって, 原料执よび製造型式が変り，それに伴っ て, 微生物の動態, 酵母の有機酸代謝型式が異なり，ひ いては清酒の有機酸組成が異なってくることは充分考兄 られ，今後これら未解決な点を逐次検討して行きたいと 思っている。

一方，清酒醸造に扮いて，腐造を防ぐのはもちろんで あるが，定常性のある醸造を行ならことが，その酒造場 に和いて特徵あるしかも一定の品質の清酒をつくる必須 の条件であると思われる。酛, 醪の発酵管理としては, 状貌一般分析抢よび TTC 染色, 酵母数, 細菌数などの 微生物管理とともに, 酢酸を測定し, 微生物の動きを常 に把握することが肝要であらう。

本稿を終觉るに当り，著者らの研究に対し貴重な試料
を御提供戴いた各酒造会社に厚く御礼申上げます。

$$
\text { 文献 }
$$

1）清酒釀造に括ける有機酸の研究

（第 1 報） 米，敕，酛，醪，清酒扣よび酒粕中の有機酸組 成につい て, 上田, 林田, 北川: 酘工, 38, 337 (1960)

（第 2 報）酒造用玄米の有機酸組成，林田，北川，上田，豊沢，米崎 : 醊工, 42, 15 (1964)

（第 3 報） 米粒各部位の有機酸組成，林田，上田，寺本，米崎，豊沢 : 酸工, 43,85 (1965)

（第 4 報）製数中の有機酸の変化，林田，北川，户田，上田，寺本： 醀工, 43, 93 (1965)

（第 5 報） 各種酘の有機酸含量の比較，林田，上田，寺本 : 醱工， 45 103 (1967)

（第 6 報）清酒醪に执ける有機酸の経時的変化, 林田, 上田, 寺本 : 醱工, 46, 77 (1968)

（第 7 報） 清酒中の有機酸組成の多様性について，林田，上田，寺本 : 醊工, 46, 85 (1968)

2）各種酛に批ける有機酸の消長，森，渡辺，上田，北川：䤇工，38, $581(1960)$

3）清酒酽造工業の原料利用率に関する研究

（第 9 報）有機酸生成のための炭水化物の損失, 豊沢, 米崎, 上田・ 林田, 醱工, 38，343 (1960)

4）発醉工業の生産管理に対する有機酸分析の応用，上田，林田，寺本 : 工化誌, 67, 753 (1964)

5) 醊醉乳酸の利用に関する研究

（第11報）市販乳酸の重合物組成，上田，寺島，奥田：醴工， $36 ， 368$ (1958)

（第12報）稀勫による乳酸重合物の変化, 上田, 寺島 : 醱工, 36 , 371 , (1958)

6）国産シリカゲルによる有機酸の定量，豊島，上田：醱工，38, 230 (1960)

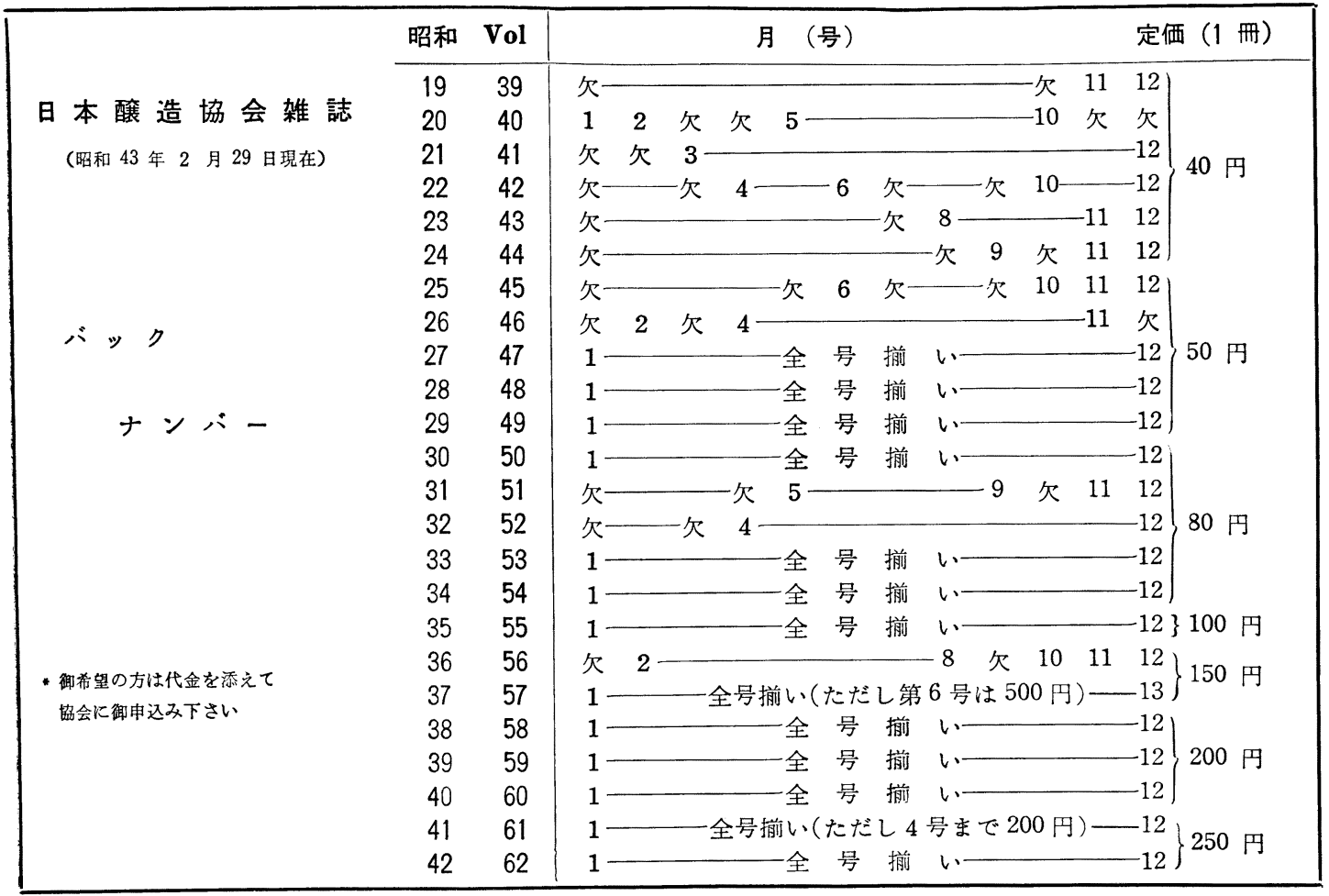

